\title{
Stimulation of Granulation Tissue Formation by Platelet-derived Growth Factor in Normal and Diabetic Rats
}

\author{
Gary R. Grotendorst, George R. Martin, Dobromir Pencev, Jaro Sodek, and Anita K. Harvey \\ Laboratory of Developmental Biology and Anomalies, National Institute of Dental Research, National Institutes of Health, Bethesda, \\ Maryland 20205; Department of Gastroenterology, University Hospital Steglitz, Berlin, Federal Republic of Germany; and \\ Faculty of Dentistry, University of Toronto, Toronto, Ontario, Canada
}

\begin{abstract}
Subcutaneous implantation of Hunt-Schilling wound chambers in rats induces a wound repair response causing the chamber first to fill with fluid and subsequently with connective tissue. The presence of a type I collagen gel encouraged a more rapid dispersion of cells throughout the chamber but had no effect on the rate of new collagen deposition. Addition of platelet-derived growth factor (PDGF; $50 \mathrm{ng} / \mathrm{chamber}$ ) to the collagen-filled chambers caused an earlier influx of connective tissue cells, a marked increase in DNA synthesis, and a greater collagen deposition in the chamber during the first 2 wk after implantation. After 3 wk, however, the levels of collagen were śimilar in PDGFsupplemented and control chambers. Diabetic animals exhibited a decreased rate of repair which was restored to normal by addition of PDGF to the wound chamber. Combinations of PDGF and insulin caused an even more rapid increase in collagen deposition. These results suggest that the levels of various growth factors, particularly PDGF, may be limiting at wound sites and that supplementation of wounds with these factors can accelerate the rate of new tissue formation.
\end{abstract}

\section{Introduction}

The repair of damaged tissue occurs through the concerted action of many specialized cell types which invade the wound in an ordered sequence (1-8). Recent studies have identified some of the factors, including chemoattractants, attachment factors, and growth factors, which are required for the entry, migration, and proliferation of cells in the wound (6-8). It is possible that in areas of extensive trauma, in patients with diseases such as diabetes, and in individuals receiving certain drugs, the production of these factors is not sufficient to maintain normal healing. In such cases, as well as in normal individuals, it may be possible to increase the rate of repair by adding factors directly to the wound site.

The migration of cells into a wound is thought to be determined in large part by the production of chemoattractants, i.e., chemicals that promote the directed movement of responding cells. A variety of such attractants has been described in in vitro tests for certain cells. Inflammatory cells respond to che-

Address correspondence to Dr. Grotendorst. Dr. Grotendorst's present address is Medical University of South Carolina, Department of Medicine, Division of Rheumatology and Immunology, 171 Ashley Ave., Charleston, SC 29425.

Received for publication 18 March 1985 and in revised form 27 August 1985

J. Clin. Invest.

(C) The American Society for Clinical Investigation, Inc.

0021-9738/85/12/2323/07 \$1.00

Volume 76, December 1985, 2323-2329 moattractants which would be present at wound sites, including complement peptides (9), platelet-derived peptides (10-12), and bacterial products (13-15). Endothelial cells are attracted by still other factors that are not yet well characterized (16). Fibroblastic cells respond to a different sêt of chemotactic factors, including fibronectin $(17,18)$, lymphokines (19), and platelet-derived growth factor (PDGF) $)^{1}(20-23)$. PDGF is a basic protein $\left(M_{\mathrm{r}}\right.$ $=31,000)$ which is stored in the $\alpha$-granules of platelets (24). PDGF has dual activities, being both chemotactic and mitogenic for fibroblastic cells (20-27). Other growth factors including epidermal growth factor (EGF), fibroblast growth factor (FGF), and insulin are not active as chemoattractants. The mitogenic action of PDGF is dependent on the presence of growth factors contained in plasma $(24,26,27)$, whereas the chemotactic activity of PDGF is not (21).

To test the ability of growth factors to stimulate wound repair, we have used a model system employing Hunt-Schilling chambers (HSC) $(28,29)$. When implanted subcutaneously, these stainless steel chambers have been shown to induce a wound repair response; they fill initially with granulation tissue and finally with new connective tissue. We modified the chambers by filling them with a collagen gel and various growth factors. This had two advantages. First, the collagen gel allowed cells to penetrate throughout the chamber, whereas tissue was deposited initially on the inner surface of empty chambers. Secondly, supplements were maintained in the chambers containing collagen gels for a much longer period than in chambers lacking the gel (data not shown). These chambers have advantages in that they allow comparable quantities of material to be isolated, and they serve as a localized target in which to test biologically active supplements. Sporn et al. (30) have measured the deposition of collagen in stainless steel mesh chambers either with or without supplements of the transforming growth factors, TGF- $\alpha$ and TGF- $\beta$. They found a more rapid deposition of connective tissue in the presence of TGFs.

Using this same model, we have tested the ability of various growth promoting factors (PDGF, EGF, and insulin) to stimulate the rate of wound repair in normal and diabetic rats where wound healing is delayed. Our results show that the addition of PDGF to wounds can enhance the rate of new tissue formation, indicating that the levels of PDGF available in wounds may be suboptimal in wounds or in traumatized sites in both normal and diabetic animals.

\section{Methods}

Preparation of collagen, growth factors, and collagen matrices. PDGF was purified to $>90 \%$ purity using a modification of established methods

1. Abbreviations used in this paper: EGF, epidermal growth factor; FGF, fibroblast growth factor, HSC, Hunt-Schilling chambers; PDGF, plateletderived growth factor; TGF, transforming growth factor. 
$(31,32)$ as described previously (25). EGF was obtained from Collaborative Research, Inc. (Waltham, MA). All growth factors were tested for mitogenic activity as described previously $(21,25)$. Insulin was purchased from Sigma Chemical Co. (St. Louis, MO). Collagen was isolated from rat tail tendon as described by Bornstein and Piez (33). In some experiments, bovine collagen (Vitrogen; Collagen Corp., Palo Alto, CA) was used in place of the rat tail collagen and caused an identical repair reaction to that observed with the homologous protein. Collagenous matrices were formed by neutralizing a solution of collagen in $10 \mathrm{mM} \mathrm{HCl}$ at $4^{\circ} \mathrm{C}$ with $2 \mathrm{M}$ Tris- $\mathrm{HCl}, \mathrm{pH} 7.4$, until the solution was $0.2 \mathrm{M}$ Tris, $\mathrm{pH}$ 7.4. Gentamycin $(100 \mu \mathrm{g} / \mathrm{ml})$ as well as the growth factors to be tested were added to the solution. The solution was then mixed thoroughly with a magnetic stirrer and pipetted into $17 \times 100$-mm polystyrene test tubes (Falcon Labware, Oxnard, CA). Six chambers were submerged in each tube and carefully freed of trapped air. The tubes were transferred to a $37^{\circ} \mathrm{C}$ water bath for $1 \mathrm{~h}$ to initiate the formation of a collagen gel. We removed the chambers from the tubes immediately before implantation by cracking the tube with pliers and allowing the collagen gel to slide out into a dish containing sterile saline. Before implantation, excess collagen gel was removed with a spatula from the outside of the chambers.

Implantation of chambers. Female Sprague-Dawley rats $(200 \mathrm{~g})$ were anesthetized with pentobarbitol $(50 \mathrm{mg} / \mathrm{kg})$ by intraperitoneal injection. The dorsal side of the rat was then shaved and three longitudinal incisions $(3 \mathrm{~cm}$ each) were made on both the left and right flank of each animal. Pockets were formed along the sides of the animals under the paniculus carnosis and the chambers $(1.5 \mathrm{~cm}$ long $\times 1.0 \mathrm{~cm}$ diameter; volume $=1.2 \mathrm{~cm}^{3}$ ) were inserted. The wounds were closed with three or four metal clips. Control chambers containing only collagen were implanted on the left flank of the animal and treated chambers were implanted in the right flank. Rats receiving implants survived the operation well with no infection or evidence of postoperative discomfort.

Induction of diabetic state. Diabetes was induced in normal SpragueDawley rats by a single intravenous injection of streptozotocin $(60 \mathrm{mg} /$ $\mathrm{kg}$ ) via the tail vein. The animals were kept on $5 \%$ dextrose in water for $24 \mathrm{~h}$ after injection and then on unlimited water and rat chow. Serum glucose was determined $5 \mathrm{~d}$ after injection by a glucose oxidase assay (34). Normal rats had serum glucose levels of $100 \pm 20 \mathrm{mg} / \mathrm{dl} .90 \%$ of al treated rats had serum glucose levels $>300 \mathrm{mg} / \mathrm{dl}$. For our studies, we chose only those rats whose serum glucose levels ranged between 350 and $500 \mathrm{mg} / \mathrm{dl}$. Chambers were implanted on the fifth day after streptozotocin injection. In one series, the animals were maintained on intramuscular injections of insulin (Ultralente Iletin I Insulin, 2 U/d, Eli Lilly \& Co., Indianapolis, IN). The insulin treatment lowered the serum glucose to $<200 \mathrm{mg} / \mathrm{dl}$.

Analysis of chamber contents. Animals were sacrificed by $\mathrm{CO}_{2}$ asphyxiation on the indicated days after implantation, and the chambers were removed surgically. A fibrous capsule which formed outside of the chambers was carefully removed by dissection before the processing of the chambers. Chambers from the most anterior site were fixed in phosphate-buffered saline (PBS)/formalin (3.7\%) and used for histological studies. The middle pair was extracted with $1 \mathrm{~N} \mathrm{NH}_{4} \mathrm{OH} / 0.1 \% \mathrm{TX}-100$ and a sample was hydrolyzed with $6 \mathrm{~N} \mathrm{HCl}$ for $24 \mathrm{~h}$ at $105^{\circ} \mathrm{C}$ for amino acid analysis. The most caudal pair was used to determine the rate of DNA synthesis as described below.

Histology. The tissue contained in the chambers was stored in PBS/ formalin $(3.7 \%)$ until samples from all the time points had been collected. The fixed tissue was then removed from the chambers, embedded in paraffin, and six 10- $\mu \mathrm{m}$ sections were cut and stained with hematoxylineosin. The sections were viewed with a Zeiss photomicroscope III (Carl Zeiss, Inc., Thornwood, NY). 10 fields from each data point were observed. Some variation between fields of the same section were seen, although these were not as great as the differences between two experimental groups. Fields that represented the mean of those observed were photographed.

Total collagen content. The contents of the chambers were solubilized by extracting each chamber with $5 \mathrm{ml}$ of $1 \mathrm{~N} \mathrm{NH}_{4} \mathrm{OH} / 0.1 \% \mathrm{TX}-100$ at $100^{\circ} \mathrm{C}$ for $2 \mathrm{~h}$. An aliquot of the extract was then hydrolyzed in $6 \mathrm{~N}$ $\mathrm{HCl}$ at $105^{\circ} \mathrm{C}$ for $24 \mathrm{~h}$ and subjected to amino acid analysis with a Durrum amino acid analyzer (Dionex Corp., Sunnyvale, CA). The amount of hydroxyproline was measured, and the amount of collagen was calculated assuming 100 residues of hydroxyproline per collagen $\alpha$-chain (35)

DNA synthesis. The excised chambers with enclosed tissue were incubated in $5 \mathrm{ml}$ Dulbecco's modified Eagle's medium containing $2 \mathrm{mg} /$ $\mathrm{ml}$ bovine serum albumin (BSA) and $2 \mu \mathrm{Ci} / \mathrm{ml} \mathrm{[}{ }^{3} \mathrm{H}$ ]thymidine (New England Nuclear, Boston, MA) for $4 \mathrm{~h}$ at $37^{\circ} \mathrm{C}$ in an atmosphere of $90 \%$ air/10\% $\mathrm{CO}_{2}$. The chambers were then washed three times with PBS and the contents were extracted with $1 \mathrm{~N} \mathrm{NH}_{4} \mathrm{OH} / 0.1 \% \mathrm{TX}-100$ at $100^{\circ} \mathrm{C}$ for $2 \mathrm{~h}$. An aliquot of the extract was precipitated with $10 \% \mathrm{TCA}$ at $4^{\circ} \mathrm{C}$ and the $\left[{ }^{3} \mathrm{H}\right]$ thymidine incorporated into TCA-precipitable material was determined. The total DNA content was measured using the fluorometric procedure of Brunk et al. (36). DNA synthesis is expressed as the amount of $\left[{ }^{3} \mathrm{H}\right]$ thymidine incorporated per microgram of total DNA.

\section{Results}

Effects of the collagen gel on the rate of new tissue formation in HSC. Implantation of empty HSC induces a repair response during which new connective tissue is deposited on the inner surface and later throughout the chamber. We first determined whether the addition of a collagenous matrix to the chamber altered the formation of new connective tissue. Empty chambers and chambers filled with a type I collagen gel were implanted in animals. After growth for 2, 5, 7, 10, 15, and $20 \mathrm{~d}$, the animals were sacrificed, the chambers were removed, and the hydroxyproline content was determined (Fig. 1). No new collagen was detected by $7 \mathrm{~d}$ after implantation in either the empty or collagen gel-containing chambers since in any wound there is a lag in new tissue deposition. Between 10 and $20 \mathrm{~d}$, the rate of deposition of new collagen in both the empty and collagen-filled chambers was nearly identical (Fig. 1), indicating that the presence of the collagen gel did not affect the rate of new extracellular matrix formation within the chambers. For this reason, collagen-filled chambers were used in subsequent experiments as a support and vehicle for growth factors.

PDGF stimulation of granulation tissue formation. PDGF has been shown to stimulate both the migration $(20-23,25)$ and growth $(24,26,27)$ of connective tissue cells in vitro. It is likely that the release of this factor during platelet aggregation is involved in recruiting connective tissue cells to the site of injury.

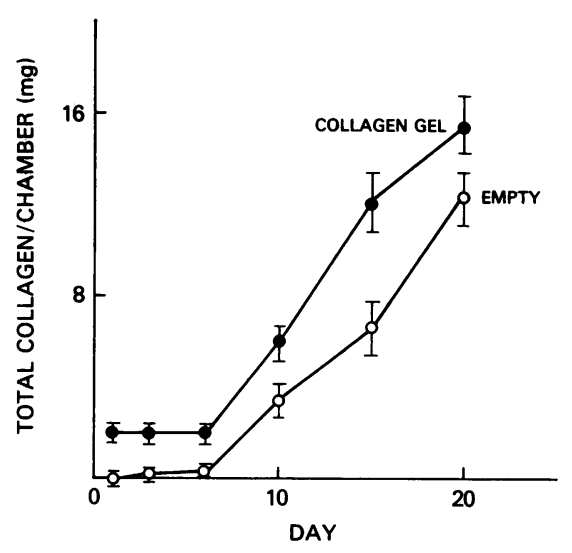

Figure 1. Deposition of newly synthesized collagen with time after implantation in empty and in collagen gel-filled chambers. Empty chambers were implanted on the left flank and collagen-filled chambers on the right flank of female Sprague-Dawley rats $(200 \mathrm{~g})$. The chambers were removed at the indicated days and the amount of new collagen deposited was determined by hydroxyproline analysis as described in Methods. The amount of newly synthesized collagen has been corrected for the collagen present in the chamber at the time of implantation. Data are the mean $\pm \mathrm{SD}$ of three separate chambers. 

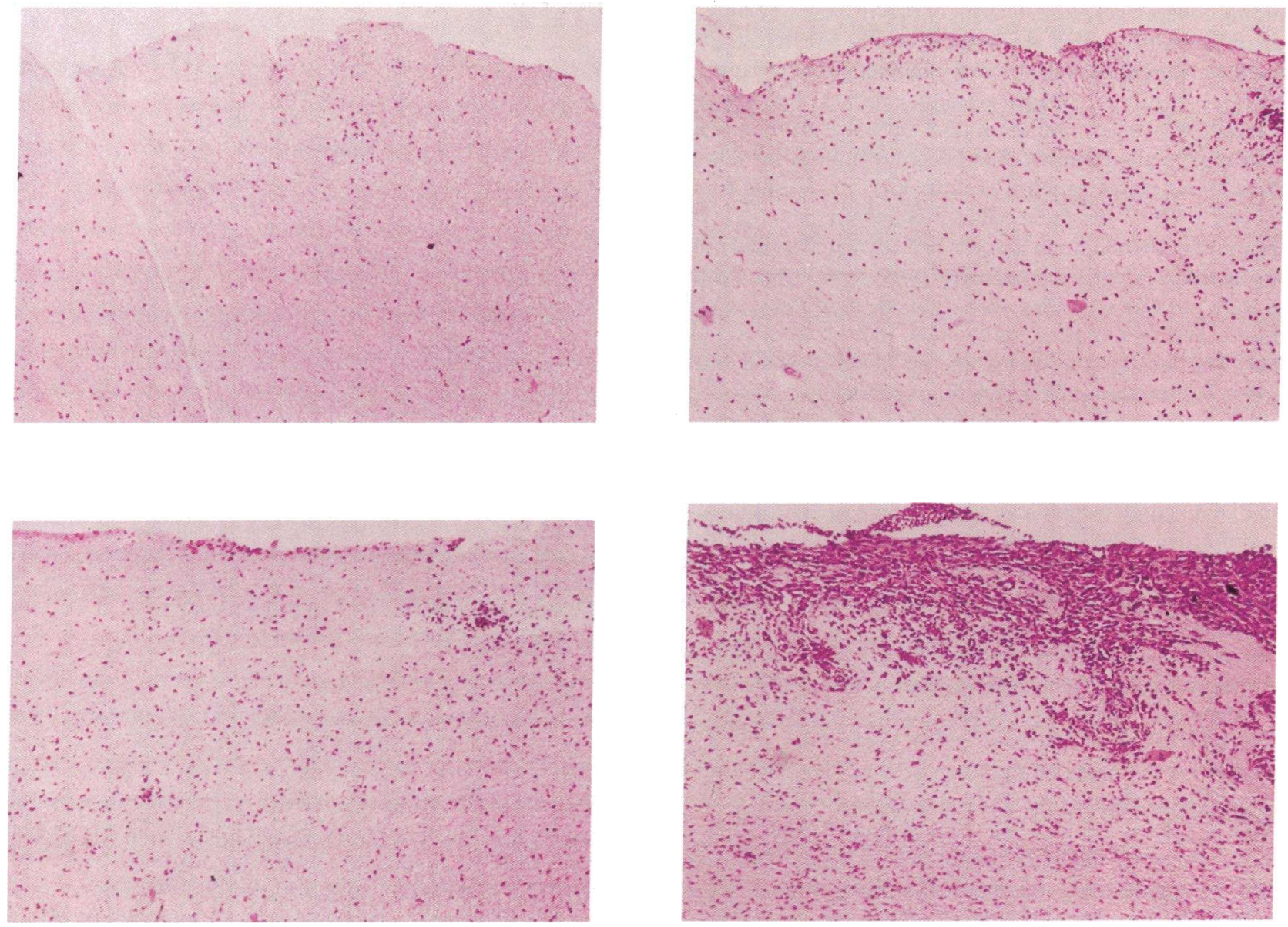

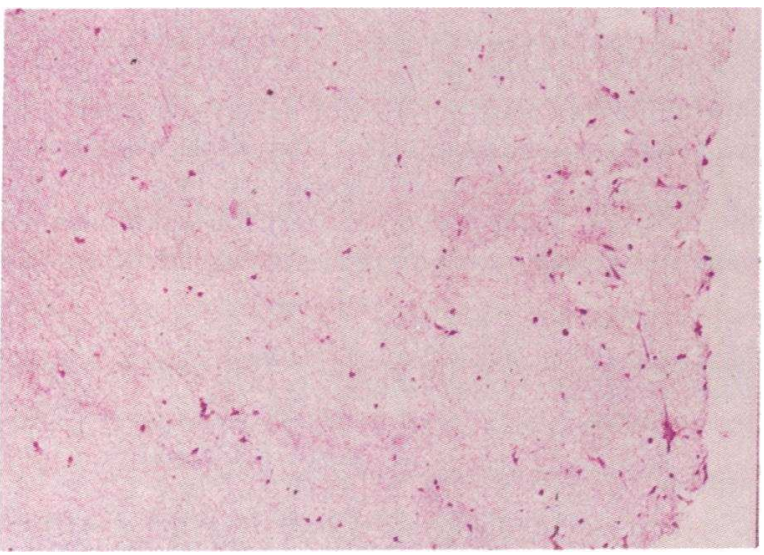

Figure 2. Acceleration of new tissue ingrowth by PDGF. Control chambers (collagen, $2 \mathrm{mg} / \mathrm{ml}$ ) and PDGF-containing chambers (collagen, $2 \mathrm{mg} / \mathrm{ml}$; PDGF, $50 \mathrm{ng} / \mathrm{ml}$ ) were implanted in rats and the contents were analyzed with a light microscope on days 3,6 , and 10 . Sections $(10 \mu \mathrm{m})$ from formalin (3.7\%)-fixed tissue were stained with hematoxylin and eosin and were mounted on glass microscope slide. Photomicrographs were taken with a Zeiss photomicroscope III (Carl Zeiss, Inc., Thornwood, NY) using the $\times 100$ objective. The control

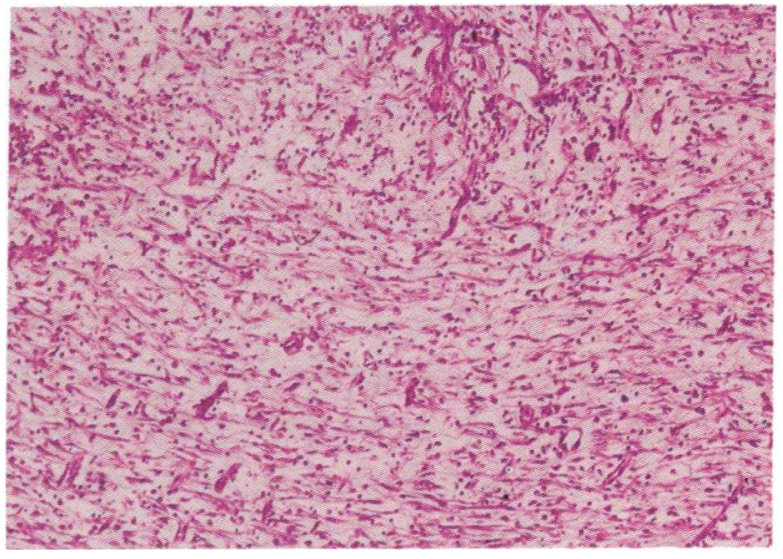

chambers (left column; days 3,6, and 10; top, middle, and bottom, respectively) contain primarily neutrophils with few macrophages or fibroblastic cells. PDGF-containing chambers (right column) show similar levels of neutrophils and macrophages on days 3 (top) and 6 (middle). In contrast with the controls, PDGF-containing chambers exhibit significant ingrowth of granulation tissue on days 6 (right, middle) and 10 (right, bottom). 
To test the effect of PDGF on wound repair, wound chambers containing collagen gel plus $50 \mathrm{ng} / \mathrm{ml}$ of PDGF were implanted. The chambers were excised at various intervals. When histological sections from the PDGF-treated chambers were compared with control chambers (collagen gel alone), they showed a much more rapid cellular accumulation and matrix deposition (Fig. 2). Nonsupplemented control chambers were infiltrated by large numbers of leukocytes, primarily neutrophils ( $>95 \%$ ), and some monocytes by day 3 and these cells remained past day 5 . By day 10 , the number of inflammatory cells had decreased so that only a few remained. These cells appeared to be monocytes. Fibroblasts were not observed until day 10 in the nonsupplemented chambers, and at this time, only a few individual cells were present. The leukocyte response in the PDGF-supplemented chambers was similar to that of the nonsupplemented chambers. However, large numbers of fibroblasts were present by day 6 with areas of newly deposited connective tissue forming at the edges of the chamber. Extensive granulation tissue was found in the PDGF-supplemented chambers by day 10 with abundant new connective tissue deposition as well as many fibroblastic cells and capillaries. These data suggest that PDGF stimulates an increased rate of granulation tissue formation but not an increased inflammatory response.

Because it is not possible to accurately quantitate the amount of new tissue by light microscopic observation, we chose two other independent measures of tissue formation-DNA synthesis and collagen content. The level of DNA synthesis in PDGFsupplemented chambers on days 5 and 10 was greatly elevated over nontreated controls (Fig. 3). By day 20, however, the control and PDGF-treated samples had reached similar levels of DNA synthesis. Next, we analyzed the amount of new collagen deposited by quantitating the hydroxyproline content of the chamber. PDGF increased the deposition of collagen on days 5 and 10 over that observed in control chambers (Fig. 4). However, this difference in collagen deposition was transient, and by day 20 , similar amounts of collagen were present in the control and in the PDGF-containing chambers. These results indicate that PDGF enhances the initial proliferation of cells in the chamber

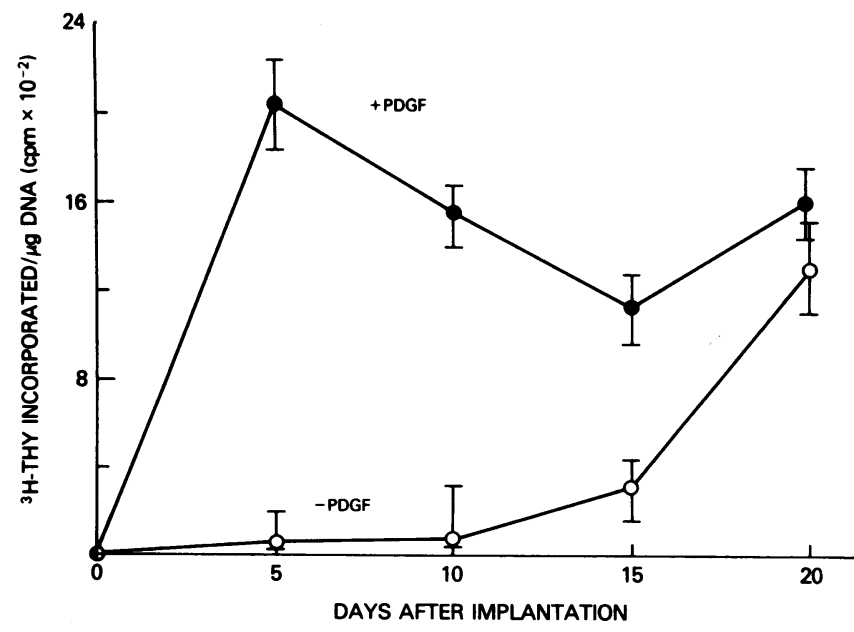

Figure 3. Stimulation of DNA synthesis in vivo by PDGF. Control and PDGF-treated chambers were removed from animals on the indicated days, incubated with $\left[{ }^{3} \mathrm{H}\right]$ thymidine $\left(\left[{ }^{3} \mathrm{H}\right] \mathrm{Thy}\right)$, and processed for DNA synthesis as described in Methods. PDGF-containing chambers exhibited significantly higher levels of DNA synthetic activity than controls on days 5 and 10 after implantation. Data are the mean $\pm S D$ of three separate chambers.

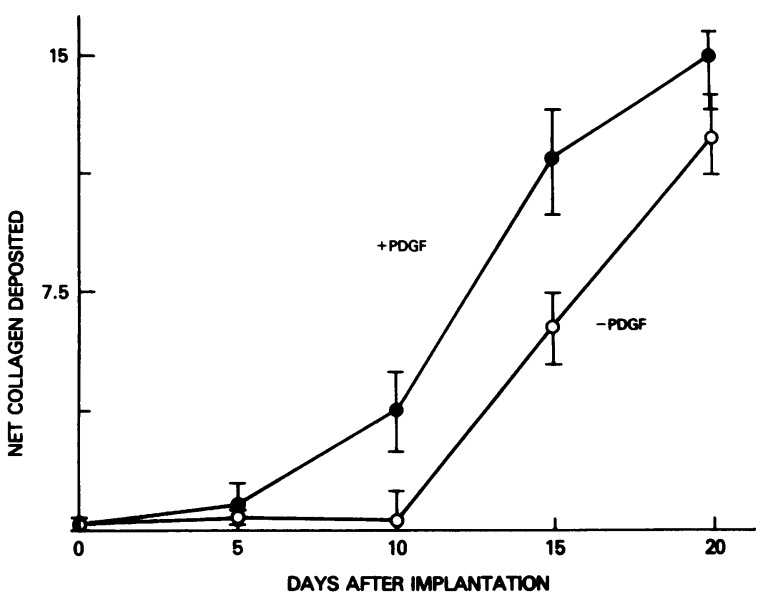

Figure 4. Stimulation of collagen deposition $\left(\mathrm{mg} / \mathrm{cm}^{3}\right.$ tissue) by PDGF. Control and PDGF-containing chambers were removed on the indicated days and analyzed for total collagen content by hydroxyproline analysis as described in Methods. The amount of newly synthesized collagen was determined after correction for the collagen present in the chambers at the time of implantation. PDGF increased the level of collagen deposition on days 5 and 10 but not on day 20. Data are the mean $\pm \mathrm{SD}$ of eight separate determinations.

and the deposition of collagen but that the unsupplemented chamber eventually reached the same level.

Stimulation of tissue formation by various growth factors. Other growth factors besides PDGF have been shown to stimulate the proliferation of connective tissue cells (37). These factors include EGF and insulin. In addition, in vitro studies have shown that PDGF plus additional growth factors are required to stimulate cell division $(26,27)$. Thus, we tested whether the addition of a combination of factors could cause an even faster rate of tissue formation. EGF showed some activity in increasing the rate of collagen deposition when added individually, whereas insulin did not (Table I). PDGF was much more active than any of the other growth factors. Chambers supplemented with a combination of PDGF and insulin showed marginally higher rates of collagen deposition than PDGF alone, suggesting that there may be sufficient levels of insulin or insulinlike growth factors in wound fluids to support maximal cell proliferation.

Effect of growth factors on repair in streptozotocin-induced

Table I. Effects of Different Factors on New Collagen Deposition in Wound Chambers

\begin{tabular}{lclll}
\hline & & \multicolumn{3}{l}{ Total collagen deposited* } \\
\cline { 3 - 5 } Factor & Amount added & Day 10 & Day 20 & Day 30 \\
\hline & & $m g /$ chamber & $m g /$ chamber & $m g /$ chamber \\
None & - & $5 \pm 1$ & $11 \pm 1$ & $19 \pm 3$ \\
EGF & $50 \mathrm{ng} / \mathrm{ml}$ & $5 \pm 1$ & $14 \pm 1$ & - \\
PDGF & $50 \mathrm{ng} / \mathrm{ml}$ & $8 \pm 1$ & $19 \pm 3$ & $22 \pm 3$ \\
Insulin & $500 \mathrm{ng} / \mathrm{ml}$ & $7 \pm 1$ & $11 \pm 2$ & $21 \pm 3$ \\
PDGF + insulin & $50 \mathrm{ng} / \mathrm{ml}$ & $8 \pm 2$ & $22 \pm 3$ & $20 \pm 2$ \\
& $+500 \mathrm{ng} / \mathrm{ml}$ & & &
\end{tabular}

* The total collagen deposited was determined as described in Methods. The amount of collagen initially added to the chambers has been subtracted from all values $(2 \mathrm{mg} / \mathrm{ml} ; 2.4 \mathrm{mg} /$ chamber $)$. The results are the mean $\pm \mathrm{SD}$ of four separate chambers. 
diabetic animals. Diabetic individuals often have impaired healing of wounds or develop chronic ulcers. It is possible that these problems are caused by decreased levels of growth factors present at the wound site. Therefore, we next investigated the effects of PDGF on wound repair in diabetic animals. Hematoxylin- and eosin-stained sections of chamber tissue from the diabetic animals appeared to contain fewer cells than in the normal animals (data not shown). As seen in Fig. 5, the hydroxyproline content of chambers in diabetic animals was only $50 \%$ of that in nondiabetic animals on days 20 and 30. This effect could be reversed by adding PDGF $(50 \mathrm{ng} / \mathrm{ml})$ to the chambers. In contrast, the addition of insulin to the chambers had no significant effect on the deposition of new collagen in either normal or diabetic animals (Table II). In addition, daily systemic insulin injections did not restore the rate of collagen deposition even though serum glucose levels were lowered by this treatment (data not shown). However, combinations of PDGF and insulin in the wound chamber stimulated a significantly larger increase in the rate of collagen deposition in the diabetic rats than either factor added alone (Table II). These data suggest that in diabetic animals both PDGF and insulin or insulinlike growth factors may be present in suboptimal levels for cell replication, whereas only PDGF appears to be limiting in nondiabetic animals.

\section{Discussion}

Trauma elicits a rapid, localized response leading to the repair, restoration, and replacement of damaged tissues. The process can be divided into the immediate reaction as blood clots and platelets aggregate, an intermediate period during which cells

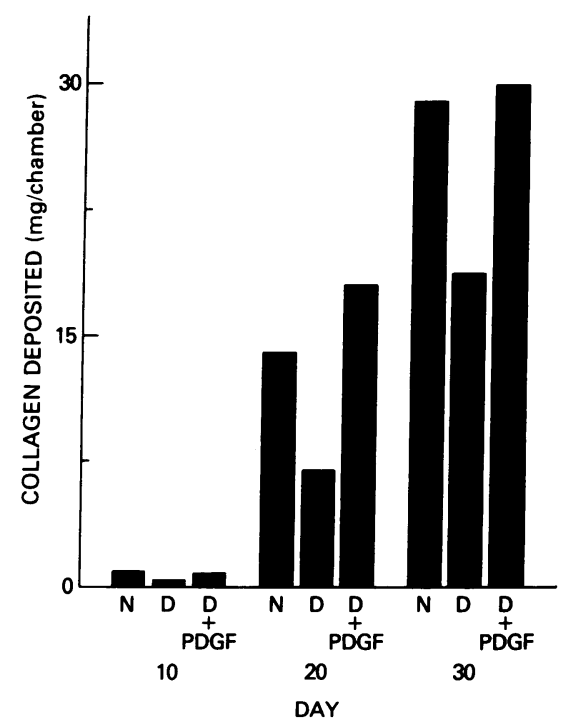

Figure 5. Effect of diabetes on collagen deposition in wound chambers. Chambers were implanted in both normal and steptozotocin-induced diabetic rats and the total collagen content was determined by hydroxyproline analysis as described in Methods. The amount of newly synthesized collagen was determined after correction for the collagen initially added to the chambers. Diabetic animals exhibited a $50 \%$ reduction in the amount of hydroxyproline present on days 20 and 30 after implantation compared with normal animals. Supplementation of the chambers with PDGF $(50 \mathrm{ng} / \mathrm{ml})$ restored the rate of collagen deposition in the diabetic animals to a level similar to that of the nonsupplemented normal animals. Data are the mean value of four separate chambers. The results varied by less than $\pm 15 \%$ in each group.
Table II. Effects of Insulin and PDGF on New Tissue Formation in Normal and Diabetic Rats

\begin{tabular}{llc}
\hline & \multicolumn{2}{l}{ Collagen deposited* } \\
\cline { 2 - 3 } Factors added & Normal & Diabetic \\
\hline & $m g /$ chamber & $m g /$ chamber \\
None & $9 \pm 2$ & $5 \pm 2$ \\
PDGF $(50 \mathrm{ng} / \mathrm{ml})$ & $18 \pm 4$ & $11 \pm 2$ \\
Insulin $(500 \mathrm{ng} / \mathrm{ml})$ & $11 \pm 2$ & $7 \pm 1$ \\
PDGF $(50 \mathrm{ng} / \mathrm{ml})+$ insulin $(500 \mathrm{ng} / \mathrm{ml})$ & $21 \pm 3$ & $15 \pm 2$ \\
& & \\
\hline
\end{tabular}

* Collagen gel-filled chambers supplemented with the indicated factors were implanted and processed for total collagen content on day 15 after implantation as described in Methods. Diabetes was induced by a single injection of steptozotocin $4 \mathrm{~d}$ before implanting the chambers. Data are expressed as the amount of total collagen present minus that amount present in the initial gel $(2 \mathrm{mg} / \mathrm{ml} ; 2.4 \mathrm{mg} / \mathrm{chamber})$. The data are the mean \pm SD of four separate chambers.

accumulate in the wound, and a long slow process where collagen accumulates and restores the tensile strength of the wound. Considerable evidence suggests that local factors generated by tissue damage or clotting initiate and sustain the repair process (6-8). It is our postulate that the penetration of new connective tissue cells into the wound limits the rate of repair, and that this process can be accelerated by supplementing wounds with factors that attract cells into the wound site and increase their proliferation.

The wound response to HSC resembles the response to other wound models with regard to the order in which cells enter the wound, the lag before collagen deposition, the rate and kinds of collagen deposited, and the appearance of new blood vessels (28, 29). However, this model is quite distinct from linear incisions and full thickness skin wounds as there is, for example, no epithelialization. In sum, the stainless steel mesh chamber represents a convenient model for studying quantitative aspects of wound healing, although it is possible that it differs in critical ways from the response elicited in other wound models.

Various mitogens including EGF, FGF, PDGF, and insulin were added to the chambers and their effect on wound healing was determined. Particular attention was directed toward the PDGF because it acts as a potent chemoattractant and mitogen for fibroblastic cells (20-27). As little as $50 \mathrm{ng} / \mathrm{ml}$ of PDGF caused as much as a twofold increase in collagen deposition and a substantial stimulation of cell proliferation $10 \mathrm{~d}$ post implantation. Interestingly, at $20 \mathrm{~d}$, the nonsupplemented chambers approached the levels of collagen deposition and of DNA synthesis observed in the treated chambers. This suggests that a single addition of PDGF accelerates the wound repair response but does not cause a hypertrophic response. This is most probably due to the diffusion of PDGF from the chambers after the first 5-10 d.

Other growth factors were tested for their ability to stimulate collagen deposition in the wound chamber. EGF and FGF showed some enhancement of collagen deposition over nonsupplemented chambers, whereas insulin did not. $N$-formylmethionyl-leucine-phenylalanine, a potent chemotactic factor for phagocytic cells (13), did not influence the deposition of collagen (unpublished observations). Combinations of the growth factors, particularly PDGF and insulin, showed a somewhat greater response than PDGF alone. This is expected as PDGF 
is not able to stimulate cell proliferation alone and requires progression factors such as insulin or the somatomedins to complete cellular replication $(26,27)$. Because the effects of insulin and EGF were minimal, it is likely that they are not limiting in the wounds of normal animals, or that the chemotactic activity of PDGF is more important than its mitogenic activity in this system.

The wound repair response was considerably reduced in diabetic animals and returned to near that of the nonsupplemented chambers in normal animals by local supplementation of PDGF. Systemic injections of insulin lowered serum glucose levels in diabetic animals but did not restore wound healing to normal; this was possibly because local levels of insulin are not sufficiently high or are not maintained. Addition of insulin alone to the chambers had no effect on blood glucose levels or on the rate of new tissue formation within the chamber. However, combinations of PDGF and insulin stimulated a greater deposition of new collagen than either growth factor added alone. These results suggest that combinations of PDGF and insulin, when added locally to wounds in diabetics, may increase the rate of repair of injured tissue. Presently it is not clear whether the levels of these factors are lower in diabetic animals or if the diabetic state makes the cells less responsive to PDGF. Because diabetics have poor peripheral circulation, the blood supply present at the time of wounding could deliver decreased levels of PDGF and other factors to the wound site.

In summary, it appears that the rate of repair in normal animals is not maximal and may be limited in part by the levels of chemoattractants and growth factors present at the wound site. It is probable that both the penetration of cells into the wound and their subsequent proliferation are rate-limiting events which must occur before the deposition of new collagen and the extracellular matrix. Addition of factors, such as chemoattractants and mitogens for connective tissue cells, could stimulate the overall rate of repair by accelerating the influx of these cells into the wound site. This may be of particular importance in individuals who have poor wound healing, such as diabetics.

\section{Acknowledgments}

This work was supported in part by a grant from the Collagen Corp., Palo Alto, CA.

\section{References}

1. Ross, R., and E. P. Benditt. 1961. Wound healing and collagen formation. I. Sequential changes in components of guinea pig skin wounds observed in the electron microscope. J. Biophys. Biochem. Cytol. 11: 677-665.

2. Ross, R. 1969. Wound healing. Sci. Am. 220:40-50.

3. Howes, R. M., and J. E. Hoopes. 1977. Current concepts in wound healing. Clin. Plast. Surg. 2:172-179.

4. Dieglemann, R. F., K. Cohen, and A. M. Kaplan. 1981. The role of macrophages in wound repair: a review. Plast. Reconstr. Surg. 68: 107-113.

5. Hunt, T. K., D. R. Knighton, K. K. Thakial, W. Andrews, and D. Michaeli. 1984. Cellular control of repair. In Soft and Hard Tissue Repair. T. K. Hunt, R. B. Heppenstall, E. Pines, and D. Rovee, editors. Praeger, New York. 3-19.

6. Grotendorst, G. R., D. Pencev, G. R. Martin, and J. Sodek. 1984. Molecular mediators of tissue repair. In Soft and Hard Tissue Repair. T. K. Hunt, R. B. Heppenstall, E. Pines, and D. Rovee editors. Praeger, New York. 20-40.
7. Grotendorst, G. R. 1984. Can collagen metabolism be controlled? J. Trauma. 24:S49-54.

8. Deuel, T. F., and J. S. Huang. 1974. Platelet-derived growth factor. Structure, function, and roles in normal and transformed cells. J. Clin. Invest. 74:669-676.

9. Snyderman, R., J. Phillips, and S. E. Mergenhagen. 1970. Polymorphonuclear leukocyte chemotactic activity in rabbit serum and guinea pig serum treated with immune complexes: evidence for $\mathrm{C}_{5 \mathrm{a}}$ as the major chemotactic factor. Infect. Immun. 1:521-525.

10. Deuel, T. F., R. M. Senior, D. Chang, G. Griffin, R. L. Hemilsson, and E. T. Kaiser. 1981. Platelet factor 4 is chemotactic for neutrophils and monocytes. Proc. Natl. Acad. Sci. USA. 78:4584-4587.

11. Deuel, T. F., R. M. Senior, J. S. Huang, and G. L. Griffin. 1982. Chemotaxis of monocytes and neutrophils to platelet-derived growth factor. J. Clin. Invest. 69:1046-1049.

12. Williams, L. T., H. N. Antoniades, and E. J. Goetzl. 1983. Plateletderived growth factor stimulates mouse 3T3 cell mitogenesis and leukocyte chemotaxis through different structural determinants. J. Clin. Invest. 72:1759-1763.

13. Ward, P. A., I. H. Lepow, and L. J. Newman. 1968. Bacterial factors chemotactic for polymorphonuclear leukocytes. Am. J. Pathol. 52:725-736.

14. Schiffmann, E., H. V. Showell, B. A. Corcoran, P. A. Ward, E. Smith, and E. L. Becker. 1975. The isolation and partial characterization of neutrophil chemotactic factors from Escherichia coli. J. Immunol. 114:1831-1837.

15. Schiffmann, E., B. A. Corcoran, and S. M. Wahl. 1975. $N$-formylmethionyl peptides as chemoattractants for leukocytes. Proc. Natl. Acad. Sci. USA. 72:1059-1062.

16. Banda, M. J., D. R. Knighton, T. K. Hunt, and Z. Werb. 1982. Isolation of a nonmitogenic angiogenesis factor from wound fluid. Proc. Natl. Acad. Sci. USA. 79:7775-7777.

17. Gauss-Müller, V., H. K. Kleinman, G. R. Martin, and E. Schiffmann. 1980. Role of attachment factors and attractants in fibroblast chemotaxis. J. Lab. Clin. Med. 96:1071-1080.

18. Postlethwaite, A. E., J. Keski-Oja, G. Balian, and A. Kang. 1981. Induction of fibroblast chemotaxis by fibronectin. Localization of chemotactic region to a 140,000 molecular weight non-gelatin binding fragment. J. Exp. Med. 153:494-499.

19. Postlethwaite, A. E., R. Snyderman, and A. H. Kang. 1976. Chemotactic attraction of human fibroblasts to a lymphocyte-derived factor. J. Exp. Med. 144:1188-1303.

20. Grotendorst, G. R., H. E. J. Seppä, H. K. Kleinman, and G. R. Martin. 1981. Attachment of smooth muscle cells to collagens and their migration toward platelet-derived growth factor. Proc. Natl. Acad. Sci. USA. 78:3669-3672.

21. Grotendorst, G. R., T. Chang, S. I. Seppä, E. Schiffmann, and G. R. Martin. 1982. Platelet-derived growth factor is a chemoattractant for vascular smooth muscle cells. J. Cell. Physiol. 113:261-266.

22. Seppä, H. E. J., G. R. Grotendorst, S. I. Seppä, E. Schiffmann, and G. R. Martin. 1982. The platelet-derived growth factor is a chemoattractant for fibroblasts. J. Cell Biol. 92:584-588.

23. Senior, R. M., G. S. Griffin, J. S. Huang, D. A. Waly, and T. F. Deuel. 1983. Chemotactic activity of alpha granule proteins for fibroblasts. J. Cell. Biol. 96:382-385.

24. Ross, R., A. Vogel, P. Davies, E. Raines, B. Kariya, M. J. Rivest, C. Gustafson, and J. Glomset. 1979. The platelet-derived growth factor and plasma control cell proliferation. In Hormones and Cell Culture. G. H. Sato and R. Ross, editors. Cold Spring Harbor, New York. 3-16.

25. Grotendorst, G. R. 1984. Alteration of the NIH/3T3 cell chemotactic response to PDGF by transformation, growth factor and tumor promoters. Cell. 36:279-285.

26. Pledger, W. J., C. D. Stiles, H. N. Antoniades, and C. D. Scher. 1977. Induction of DNA synthesis in Balb/c 3T3 cells by serum components: reevaluation of the commitment process. Proc. Natl. Acad. Sci. USA. 74:4481-4485.

27. Vogel, A., E. Raines, B. Kariya, M. J. Rivest, and R. Ross. 1978. Coordinate control of 3T3 cell proliferation by platelet-derived growth 
factor and plasma components. Proc. Natl. Acad. Sci. USA. 75:28102814.

28. Schilling, J. A., W. Joel, and H. M. Shurley. 1959. Wound healing: a comparative study of the histochemical changes in granulation tissue contained in stainless steel wire mesh and polyvinyl sponge cylinders. Surgery (St. Louis). 46:702-710.

29. Hunt, T. K., P. Twomey, B. Zederplatt, and J. E. Dunphy. 1967. Respiratory gas tension and $\mathrm{pH}$ in healing wounds. Am. J. Surg. 114: 302-307.

30. Sporn, M. B., A. B. Roberts, J. H. Shull, J. M. Smith, J. M. Ward, and J. Sodek. 1983. Polypeptide transforming growth factors isolated from bovine sources and used for wound healing in vivo. Science (Wash. DC). 219:1329-1331.

31. Antoniades, H. N., D. C. Scher, and C. M. Stiles. 1979. Purification of human platelet-derived growth factor. Proc. Natl. Acad. Sci. USA. 76:1809-1813.

32. Heldin, C. A., B. Westermark, and A. Wasteson. 1981. Platelet- derived growth factor. Isolation by a large scale procedure and analysis of subunit composition. Biochem. J. 193:907-913.

33. Bornstein, P., and K. Piez. 1966. The nature of the intramolecular crosslinks in collagen. The separation and characterization of peptides from the crosslink region of rat skin collagen. Biochemistry. 5:34603473.

34. Yoon, J. W., T. Onodera, and A. L. Notkins. 1977. Virus-induced diabetes mellitus. VIII. Passage of encephalomyocarditis virus and severity of diabetes in susceptible and resistant strains of mice. J. Gen. Virol. 37: 225-232.

35. Piez, K. A., E. Weiss, and M. S. Lewis. 1960. The separation and characterization of the $\alpha$ - and $\beta$-components of calf skin collagen. $J$. Biol. Chem. 235:1987-1991.

36. Brunk, C. F., K. C. Jones, and T. W. James. 1979. Assay for nanogram quantities of DNA in cellular homogenates. Anal. Biochem. 92:497-500.

37. Stiles, C. D., W. J. Pledger, R. W. Tuclah, R. G. Martin, and C. D. Scher. 1980. Regulation of the Balb/3T3 cell cycle effects of growth factors. J. Supramol. Struct. 13:489-499. 